\title{
Cohesion, Multi-faithism and the Erosion of Secular Spaces in the UK: Implications for the Human Rights of Minority Women
}

\author{
Pragna Patel*
}

\begin{abstract}
This article explores the erosion of secular public culture in the UK and its implications for minority women whose bodies have become the battleground for the control of community representation. It argues that struggles for equality and secularism now overlap and have taken on a sense of urgency because it is the human rights of women that are being traded in the various social contracts that are emerging between state and the religious right minority leaderships in the UK. The increasing communalisation (involving religious and community groups mobilising solely around religious identities) of South Asian populations, in particular Muslims, reflects a form of instrumentalisation of religion by the state which has severely constrained the public space available for women to mobilise around a rights-based agenda and has also significantly narrowed the choices of women of faith.
\end{abstract}

\begin{abstract}
1 Introduction
The UK has seen a concerted assault on secular spaces in the wake of civil unrest in some of the Northern cities in 2001, the 9/11 atrocity and the $7 / 7$ London bombings of 2005. In the guise of the 'war on terror', the state's response to the threat of Islamist terrorism has been dominated by a two-pronged approach to minorities - first, to counter the direct threat of terrorism with draconian, anti-civil liberties measures; and, second, the development of a new 'cohesion' and faith-based approach to minorities to replace the previously dominant ideological framework of multiculturalism for mediation between State and minority populations.
\end{abstract}

The process of de-secularisation started in the late 1980s following the Rushdie affair, when cracks appeared in the widely held view that Britain was a secular society in all but name. The Rushdie affair and the resurgence of religious fundamentalism in all religions ${ }^{1}$ not only exposed the lack of separation between the Church of England and the State and the privileging of Christianity above other religions, but also the limits of multiculturalism which placed primacy on the preservation of religious identities of the various minorities above the need to build a democratic, secular and anti-racist culture. ${ }^{2}$ For Muslims, the Rushdie Affair marked a significant turning point when demands for recognition and equality became focused upon religious observance and identity. Other minorities quickly followed suit.

The 'war on terror' has resulted in the deliberate pursuit of domestic policies by the British state aimed at accommodating religious identity within public institutions. This is in turn, a reflection of a number of political and social trends resulting in the shrinking of secular spaces and the increasing communalisation (involving religious and community groups mobilising solely around religious identities) of South Asian populations in particular - a process which has been quietly taking place for some time.

In accommodating religion within state institutions, the state's aim ostensibly has been to contain Islamist terrorism on British soil and to construct a moderate British Islam but the process of de-secularisation is having far- 
reaching consequences in re-ordering and undermining the democratic nature of civil society with very specific consequences for all progressive struggles but especially those waged by minority women. This process is occurring hand in hand with the dismantling of the welfare state and the pursuit of a racist anti-immigration agenda. The new cohesion and faith-based approach to minorities has therefore become a political resource used by the state and the religious right in all communities to aid the de-secularisation process.

This article explores the erosion of secular public culture in the UK and its implications for minority women whose bodies have become the battleground for the control of community representation. My argument is that struggles for equality and secularism now overlap and have taken on a sense of urgency because it is the human rights of women that are being traded in the various social contracts that are emerging between state and the religious right minority leaderships in the UK.

\section{The SBS experience}

I use as my starting point a campaign waged by the Southall Black Sisters (SBS) in 2007/8 against a decision made by the local authority (Ealing Council) to cease critical funding used by SBS to provide life-saving front-line services for minority women subject to violence and abuse in the family. What began as a local funding dispute soon came to signify a much larger struggle for equality and for the right to exist as an autonomous, secular, anti-racist and feminist organisation.

SBS was first set up in 1979, comprising AfricanCaribbean and Asian women, in the midst of intense anti-racist activity. We consciously adopted a secular feminist identity, one based on a shared history of colonialism, racism and religious patriarchal control. The absence of recognition of gender power relations within the previous anti-racist movements and the absence of acknowledgement of racism within white feminist movements had resulted in the invisibility of black and minority women. It was this invisibility which gave rise to the organisation and others alike. Personally, SBS was exactly the kind of political home that I and other women like me were searching for, since it enabled us to explore and validate our experiences of racism without suppressing the problem of gender inequality within family and community. None of this was easy to do in contexts where the only legitimate struggle by many on the progressive left was perceived to be the struggle for racial equality.

Since 1982, SBS has operated as a not-for-profit, advice, advocacy and campaigning centre for black women, with a particular focus on the needs of South Asian women subject to genderbased violence. While based in West London, an area with a large South Asian population, we have a national reach. ${ }^{3}$

In 2007, Ealing Council decided to cut funding to SBS on the grounds that specialist services for black and minority women worked against the interest of 'equality', 'diversity' and 'cohesion'. Our very name and existence was deemed to be unlawful under the Race Relations Act 1976 because it excluded white women and was therefore discriminatory and divisive. Instead, in the name of 'best value' for money, the Council decided to commission a borough-wide generic domestic violence service using the funds that had previously been awarded to SBS - funds critical to SBS in meeting core costs which were not easily available from other grant-making bodies, because most prefer to fund specific projects rather than overall running costs.

We were concerned that, if left unchallenged, Ealing Council's approach would have allowed public bodies to redefine the notion of equality in ways that undermined the very concept. It had come to be defined by Ealing Council as the need to provide the same services for everyone, in an attempt to address some resentment among the white population that it was the majority white population rather than the minorities that had historically been discriminated against and 'excluded' from civic regeneration policies. The notion of equality in this sense was no longer linked to the needs of the most vulnerable and deprived, but instead viewed as reflecting the needs of the majority community. Our fear was that this approach would be replicated with confidence elsewhere in the country, leading to the widespread closure of similar organisations set up to counter racism and provide minority women with real alternatives to patriarchal community (religious and cultural based) mechanisms for dealing with disputes in the family. 
SBS therefore brought a legal challenge against Ealing Council, which culminated on 18 July 2008 when, at the High Court in London, SBS won an important affirmation of the right to exist as a secular specialist provider of domestic violence services to black and minority women.

In court, SBS submitted that Ealing Council's approach to equality in effect meant that the race equality legislation in the UK could not protect those who are historically disenfranchised and discriminated against, since it rejected the notion of positive action in addressing racism. We argued that the Council's 'one size fits all' approach was misconstrued because it ignored unequal structural relations based on class, gender and race. The SBS further argued that specialist services for minority women are needed, not only for reasons to do with language difficulties and cultural and religious pressures, but also because of the need for advice and advocacy framed within a democratic and secular ethos in complex circumstances where racism and religious fundamentalism are on the rise in the UK and worldwide.

SBS also argued that Ealing Council's approach to cohesion was fundamentally wrong because it failed to recognise that, far from causing divisions, the provision of specialist services may sometimes be necessary to address substantive inequality, and that in turn is central to achieving a more cohesive society. It was pointed out that the SBS project was in fact an example of how cohesion is achieved organically, borne out of collective struggles for human rights, and not by the imposition of ill-conceived social policies from above. It was described how black and minority women from various national, ethnic and religious backgrounds learn to co-exist in the secular space provided by the SBS. In doing so, they both tolerate religious and cultural differences and at the same time challenge religious and cultural practices that stifle their common desires and aspirations to live free from violence, abuse and from other constrictions on their lives.

The newly formed Equalities and Human Rights Commission (EHRG) which intervened at SBS's insistence also criticised Ealing Council's interpretation and implementation of the equality legislation and its policy on cohesion.
Finding in SBS's favour, Lord Justice Moses who presided over the hearing held that Ealing Council had deliberately failed to have proper regard to its duties under the Race Relations Act 1976, and had taken a flawed approach to cohesion in reaching its decision:

There is no dichotomy between the promotion of equality and cohesion and the provision of specialist services to an ethnic minority. Barriers cannot be broken down unless the victims themselves recognise that the source of help is coming from the same community and background as they do. Ealing's mistake was to believe that cohesion and equality precluded the provision of services from such a source. It seemed to believe that such services could only lawfully be provided by a single provider or consortium to victims of domestic violence throughout the borough. It appreciates that it was in error and that in certain circumstances the purposes of Section 71 and the relevant statutory code may only be met by specialist services from a specialist source. That is the importance of the name of the Southall Black Sisters. Its very name evokes home and family. ${ }^{4}$

Lord Justice Moses concluded his much celebrated judgement by safeguarding a more progressive notion of equality:

An equal society protects and promotes equality, real freedom and substantive opportunity to live in the ways people value and would choose so that everyone can flourish. An equal society recognises people's different needs, situations and goals and removes the barriers that limit what people can do and can be.

The SBS case has created a legal precedent as to the correct approach to be taken by statutory public bodies in the delivery of services and the funding of specialist organisations. The challenge has come to represent a key moment for black and minority groups and other organisations in the voluntary or third sector seeking to address the needs of the vulnerable and marginalised in society. But it has also sounded a warning bell to secular progressive minority groups.

Ealing Council's cynical use of the cohesion agenda to cut our funding has profound 
implications for the human rights of black and minority women in particular. We are acutely aware that the judgement, notwithstanding its progressive definition of equality, does not necessarily preclude fundamentalists and the religious right from claiming scarce public funding to provide faith-based services on the grounds that they are best placed to address those from the same religious background.

3 Cohesion: a new policy framework for minorities

As the SBS example so clearly shows, the cohesion approach promoted by the government, is now the dominant framework for dealing with minorities. It is a policy objective that is linked to the other overarching themes of governance in the UK today, greater civic engagement; preventing violent Muslim extremism; 'managing migration' with a view to assimilation and the shift in institutional accountability towards faithbased organisations and institutions.

Cohesion is a malleable term that has never been precisely defined by the government. Official definitions refer to cohesion as a 'process that must happen in all communities to ensure that different groups of people get on well together' (Commission on Integration and Cohesion 2007). At the national and local level, a 'cohesive' community is described as one in which there is a common 'vision and sense of belonging for all communities; where the diversity of people's different backgrounds and circumstances is appreciated and positively valued; where those from different backgrounds have similar life opportunities and where there are strong and positive relationships developing between people from different backgrounds and circumstances in the workplace, in schools and within neighbourhoods. ${ }^{5}$

While the rhetoric of cohesion appears to have laudable aims and locates the responsibility for community cohesion on all communities including the majority community, in reality, the government has linked the issue with race. Its guidance document for instance calls on local councils to develop their cohesion strategy in the context of race relations. The assumption is that it is migrants (largely Muslims) who have failed to integrate into a 'British way of life' or adopt 'British values' and are therefore responsible for the lack of cohesion in society. The SBS funding crisis illustrated this connection clearly.
The government's cohesion strategy can be traced back to July 2001 and the civil disturbances that took place in the northern UK cities of Oldham, Burnley and Bradford - areas with large Pakistani and Bangladeshi Muslim populations. These northern towns and cities are economically deprived areas historically born out of the collapse of the textile industries and the failure of social policies to redistribute resources equitably. The entire region is characterised by considerable social segregation, especially in education, social exclusion, poor housing and racism. The result has been simmering community tensions between white British and Asian British youths in particular, who have fought each other and the police in street battles, often fuelled by inflammatory right wing organisations and the media.

In implementing the 'cohesion' policy, the state followed a contradictory course. For example, far from removing racially segregated education, identified as a major divisive force in British society, the government actively promoted singlefaith schools and academies and set about creating the conditions for faith-based organisations to flourish.

In August 2006, the government announced the launch of the Commission on Integration and Cohesion to identify the ways in which local areas can foster cohesion. The Chair of the Commission was Darra Singh who was also directly responsible for the SBS funding crisis as the Chief Executive of Ealing Council. The report of the Commission 'Our Shared Future', published in June 2007, did not address structural inequality or more pertinently the contradictions of promoting faith-based organisations in achieving cohesion. While there was some acknowledgement in the report that the disturbances in the northern cities in 2001 were in part a reflection of deprivation and industrial decline, nevertheless its focus was entirely on the need to develop local-based cohesion work - largely through religious exchange networks - and it gave guidance to local authorities to avoid funding single identity groups in particular. The report also avoided addressing the problematic issue of state support for faith-based schools, especially the existence of Church of England, Catholic and Jewish schools which in turn, has fuelled resentment among other religious minorities, resulting in 
the growth of state funding of Muslim, Sikh and Hindu schools.

In 2008, the government issued a consultation document 'Guidance for Funders' (Department for Communities and Local Government 2008), which formed an important part of the government's response to the Commission on Integration and Cohesion and its report 'Our Shared Future'. The Guidance set out the government's intention to advise funders on 'practical ways in which local authorities could help build strong communities by promoting cohesion and integration locally.' Following the report, the Guidance also placed conditions on the funding of single community groups defined as third sector groups providing targeted support for single issue/identity-based community activity. These groups include black and minority groups and other equality groups, including women's groups, gay and lesbian support groups, age and disability groups and service providers. The view was that local funding should not be made available to single group projects if it 'builds resentment in others'. Following the SBS funding victory, the government withdrew the Guidance on funding for single identity groups and left it to local authorities to use their discretion on what organisations to fund or services to commission.

Local Authorities have since continued to divest themselves and their areas of their 'race' equality departments and officers and replaced them with Community Cohesion Directorates. It would appear that it is the long-standing single identity groups (more often than not, progressive and secular) that are targeted for funding cuts at the same time as encouraging faith-based groups to emerge, as discussed below. The withdrawal of funding for SBS is one high profile example but there have been others, including several Asian women's refuges, mental health and community organisations for African and Caribbean people, to name but a few.

This dual process was vividly evident at the height of SBS's funding crisis. The irony of the situation in which SBS found itself was, that at the same time that Ealing Council decided to withdraw financial assistance, Ealing's Cohesion Strategy was and continues to be dominated by the need to promote faith-based (largely Muslim) groups to deliver local welfare services (Ealing Council 2007). ${ }^{6}$
Ealing Council's Preventing Violent Extremism (PVE) (Ealing Council 2008) strategies also reflect a major preoccupation with engagement with Muslims only. Of the $£ 45$ million made available by the government for 2008-11 to local authorities to tackle extremism among Muslims, Ealing Council received a total $£ 205,000$ for 2008-9, rising to $£ 225,000$ and $£ 286,000$ for 2009-10, respectively. Ealing's PVE agenda seeks to 'gather greater understanding of the issues/concerns facing Muslim communities; provide space for greater dialogue and discussion around Muslim identity and understanding Islamic values; provide more opportunities for engagement with the wider community through volunteering and establish greater support networks for Muslim women. Under the theme of 'Engaging with Muslim Women', the Council has made a grant of $£ 35,000$ available to local groups to 'foster in young Muslim women a greater willingness to express their own views and influence their local community, a greater awareness on how to access public services offered by statutory bodies such as the Council, and a greater awareness on how to become involved in local decision-making processes. Youth services have also been provided with $£ 10,000$ to engage with Muslim girls in secondary schools through lunchtime sessions to discuss the concerns of the Muslim girls (Ealing Council 2008).

While Ealing Council maintains that the PVE focus 'compliments the emerging borough "Integration and Community Cohesion" strategy developed in 2007', in practice, the Council's PVE and Cohesion strategies are indistinguishable.

One consequence of Ealing Council's cohesion approach is that it has encouraged the development of faith-based initiatives, including the future creation of Muslim women-only projects, without any reference to the politics and ethos of such projects and even though there are no visible demands for such organisations (Ealing Council 2008). This approach is being repeated throughout the $\mathrm{UK}$ and the organisations that have so far been closed or threatened with closure are secular organisations for black and ethnic migrants, secular women's refuges for black and minority women, disability groups and rape crisis centres. Following SBS's lead, organisations confronting similar funding problems with their local authorities have 
mounted legal challenges against their Councils using the equality legislation but while some have been successful, others have not. Paradoxically, the emphasis on funding faithbased groups have led some previously secular black and minority organisations to re-fashion themselves as faith-based groups - this has the effect of reinforcing the view that questions of identity within minority communities can be reduced to questions of religious values only. Discussions with a number of anti-racist activists in the north of England have suggested that minority groups have recently adopted a faithbased identity in order to attract local authority funding that has been diverted from anti-racist projects to cohesion and preventing violent extremism work.

\section{From multiculturalism to multi-faithism}

The rise of fundamentalist leaderships in minority communities has posed a significant threat to the autonomy and fundamental freedoms of minority women in the UK. Since 2000, however, minority women have found themselves facing a more difficult and invidious battle involving not just fundamentalists but mainstream religious leadership itself - the socalled 'moderates' - who, with the demise of progressive secular institutions within minority communities, in particular black workers' support organisations, anti-racist and police monitoring groups and Asian women's refuges, are increasingly seen by the state to be fulfilling a crucial role in mediating between state and community. This is of course a process that has always occurred under multiculturalism, but what is different, is the unequivocal acknowledgement by the state that religion is a vital part of public life which cannot be ignored.

The faith-based perspective (a framework of mediation between state and community institutions based solely around religious identity), is now an integral part of the cohesion agenda. At its heart is the view that civil society is split into two groups - those that are faith based and those that are secular. There is increasing conviction in official policy that the experiences, resources and networks of people based on religious identity have been neglected in favour of secular groups (Ealing Council 2008). To correct this situation, strategies and programmes are developed to give faith-based organisations full opportunity to participate in society because they are deemed to be important sources of social capital (vital sources of civic mobilisation and social campaigning) (Ealing Council 2008). These policies and strategies effectively re-cast ethnic minority communities (especially South Asian) as 'faith communities' so, for example Asian communities are increasingly re-categorised as 'Hindu', 'Sikh' and 'Muslim' communities.

The increasing emphasis on religion and religious identities has led to the transformation of Britain from a multicultural into 'multi-faith' society, based on a model of 'integration' which views the discrimination and exclusion of many in black and minority communities not as a product of class inequality or racism, but as a historical failure to respect and facilitate religious identity within public institutions. Models of civic engagement based on notions of citizenship and respect for individual human rights, which have never been given the opportunity to take root properly, are replaced by notions of social cohesion and integration involving adherence to 'core British values'. But such adherence does not displace cultural or religious identity. In fact, the emphasis on engagement based on faith identity encourages adherence to cultural and social autonomy as well as to a core set of values which are mostly about the maintenance of public order. This is well understood by both the state and the various religious leaderships. For example, the UK's Islamic Human Rights Commission has made it clear that it sees no reason why minority communities cannot be guided by their personal religious laws, since this does not impact on social cohesion. The demand for equality is therefore substituted by the demand for greater recognition of religious diversity and the need for 'religious literacy'. That is, the need to understand the dominant theological values and traditions as espoused by religious leaders, but not the recognition of the various liberal cultural and religious and non-religious traditions within a community.

Faith groups are now to be found at the heart of the regeneration of communities and as a direct result, religion is becoming increasingly entrenched within state institutions at central and local levels, and is reflected at all levels of state policy. In all the key public institutions, the emphasis has shifted to the need to provide services that are 'sensitive to religious identities 
and values'. This has brought into the domain of religious groups, concerns which were once addressed by progressive secular anti-racist and feminist groups, including issues such as domestic violence, child protection, and the rights of black and minority offenders in the criminal justice system.

The state's multi-faith approach has opened up the space for a reactionary politics of identity based on religion to flourish and has put power and authority into the hands of religious leaders. The conflation of issues around race with religious identity as defined by the state and fundamentalist and conservative religious leaderships, has also paradoxically, led to the direct sponsorship of fundamentalist or reactionary organisations such as the Muslim Council of Great Britain, The Muslim Association and the Hindu Forum of Britain, ${ }^{7}$ all of whom claim to be 'moderates' and all of whom have enjoyed or enjoy an unprecedented influence on state policy towards minorities.

The so-called 'moderates' ${ }^{\text {' }}$ may profess to keep law and order on the streets of Britain and decry the extremists in their midst but many are linked to violent fundamentalist movements abroad where violence is routinely used to subjugate women. Nor are they moderate on the question of women's rights in the UK. Many have used the space opened up by the government's faith and cohesion agenda to put themselves forward as the 'authentic' voice of their communities and make demands which are primarily about limiting women's participation in the public sphere and maintaining the private sphere of the family as the only legitimate arena of female existence.

The state's cohesion and faith-based approach fits neatly into a wider neoconservative agenda involving the privatisation of vital state

functions. The steady demise of the welfare state cannot be underestimated, since the breach that is created has allowed religion to step in, advantaged as it is over secular groups, by its networks of membership and vast resources. Space does not allow a full discussion of the role of religion in the provision of social services in the UK, but the shifting of institutional accountability for welfare services on to religious organisations is a dangerous development. It has to be recognised that religious groups can and do play an important role in helping to combat poverty, homelessness and destitution faced by immigrants and asylum seekers for instance, but they do this while remaining in the private sector, raising funds through their own membership and from other sources. Most importantly, their users are relatively free to exercise choice in whether or not they wish to use their services. But what is harmful about the cohesion and faith-based approach is the fact that in the name of equality, religious groups are being brought into the public domain through public funding to provide services on the basis of their religious ethos and belief systems. The danger is that through need and individual circumstances coupled with a lack of alternatives, users, such as vulnerable minority women will have no choice but to use the services offered by religious organisations. Needless to say, and as the experience of women and sexual minorities shows, those who do not share the ethos and values of such organisations will find themselves discriminated against and excluded. ${ }^{9}$

\section{Minority women and the struggle for human rights}

The struggle for equality and for the human rights of all minority women in the UK is now inextricably linked to the struggle for secular spaces. The turning point in compelling feminist organisations like SBS to make explicit this connection was the Rushdie Affair and the growing power of religious fundamentalists who used the multicultural terrain to pursue a vigorous de-secularisation agenda (Southall Black Sisters 1990; Sahgal and Davies 1992). The anti-Rushdie protests created the conditions for the emergence of a culture of intolerance, fear and censorship, which remains with us in a more heightened form. Since the 1990s, we have witnessed with alarming frequency, religious fundamentalist and authoritarian ${ }^{10}$ protests to any form of dissent from an imposed religious identity, much of which has centred directly and indirectly on the control of women's sexuality. Nor are such protests confined to Muslims only. Hindus, Sikhs and Christians in the majority community have also sought to impose strict religious identity on followers by clamping down on dissent. ${ }^{11}$ It would seem that orthodox if not fundamentalist ${ }^{12}$ leaders in all religions are vying for control over the representation of their communities. In the process, what is made transparent is the re-invention of essentialist 
notions of religion as a framework for highlighting inequalities and demanding recognition. ${ }^{13}$

\section{The privatisation of family law}

The feminist and human rights scholar Karima Bennoune (2007) has stated that the struggle to keep human rights and the law separate is one of the most urgent struggles now taking place globally. She adds that the emphasis on 'freedom of religion' has overshadowed the importance of 'freedom from religion' (Bennoune 2007). This is clearly evident in recent debates and developments in respect of demands made by some Muslim organisations to incorporate aspects of personal laws (Sharia laws) in relation to the family within the English legal system, a move which is encouraged by leading figures in the judiciary and the Church of England. ${ }^{14}$

\subsection{Religious arbitration tribunals}

Family laws are increasingly at the centre of political controversies between religious groups and secular feminists in the UK. The recent creation of the Muslim Arbitration Tribunal (MAT) in the UK, set up and managed in accordance with the Arbitration Act 1996 for alternative dispute resolution in civil law cases, especially family cases in England, is an example of how religion is encroaching upon the secular legal system (Taher 2008). ${ }^{15}$ The MAT will enable arbitration (mediation by another name) of, among others, family disputes to take place in accordance with 'Islamic sacred law'. ${ }^{16}$ By existing within the framework of the Arbitration Act 1996, the MAT will ensure that its determinations can be enforced by the English courts in cases where both parties have agreed to be bound by the outcome.

Groups like SBS and Women Against Fundamentalism ${ }^{17}$ have challenged developments such as the MAT, by arguing that the demand for religious personal laws will result in the privatisation of family law and thus become the main means by which the absolute control of minority women is maintained. Such a development will in effect allow unelected and unaccountable community leaders to preside as judges and make determinations based on religious interpretations that have historically discriminated against women and legitimised their oppression within the family. Moreover, when combined with the wider gender inequality that persists in society more generally, women will find it difficult to obtain a hearing on equal terms.

It is true that if civil law principles are breached by the operation of religious tribunals like the MAT, it is open to a party to complain but that choice is illusory unless a party is actually able to complain and even then, the woman would need to convince a court that legal principles are breached. For example, to prove duress in cases of forced marriage, she would have to meet the evidentiary threshold required and this may not be easy to do. Many women do not necessarily know that their rights have been violated or will not want to be seen to be dissenting from religious norms and will not want to risk being ostracised and subject to being declared a 'bad Muslim' or 'Sikh' or 'Hindu'. Many will not complain even if there are violations of the law. Moreover, social pressures which circumscribe the choices open to women will not always be acknowledged. Cases in the English courts suggest that so far, only legal and not social compulsion is recognised. ${ }^{18}$

The existing evidence on the outcome of family disputes in the MAT, suggests that the primary concern is to keep the family intact, even in circumstances where women and children are highly vulnerable to domestic or family violence. For instance on its official website, the MAT professes only to be concerned with civil disputes and not to interfere with the criminal law process but nevertheless it is interfering in ways that undermine state protection for minority women by limiting their participation in the civil and criminal justice system, for example by diverting them away from the formal legal system towards informal, religious-based mechanisms for dispute resolution. In a number of domestic violence cases, the MAT has succeeded in reconciling women with their abusive partners without regard to their history of abuse or their general vulnerability. Indeed, the MAT has gone so far as to state that it will actively interfere in criminal cases by seeking to influence the Crown Prosecution Services to drop charges in domestic violence cases even where criminal offences may have been committed:

The MAT is unable to deal with criminal offences as we do not have jurisdiction to try such matters in the UK. However where there 
are criminal charges such as assault within the context of domestic violence, the parties will be able [to] ask MAT to assist in reaching reconciliation which is observed and approved by MAT as an independent organisation. The terms of such a reconciliation can then be passed by MAT on to the Crown Prosecution Service (CPS) through the local Police Domestic Violence Liaison Officers with a view to reconsidering the criminal charges. ${ }^{19}$

By allowing religious arbitration tribunals like the MAT to adjudicate in family disputes, the state is in effect privileging and sponsoring the most dominant, patriarchal, homophobic and authoritarian, if not fundamentalist interpretations of religions in minority communities. The incorporation of religious personal laws within the legal system formalises gender discrimination and a culturally relativist approach to family cases; adding to the immense community pressures that minority women already face to agree to mediation and governance, based on their religious identity. It signals the view that it is legitimate for minority communities to operate a second-rate justice system based on unaccountable and partial mechanisms of conflict resolution. This is in itself a racist response to demands for equality and justice, especially in view of the fact that even in countries where state-sanctioned religious laws operate, there are substantial movements, often led by women and human rights activists, for their repeal on the grounds that they are not compatible with universal human rights principles.

By accommodating religious systems of dispute resolution in family matters in the English legal system, the UK state is effectively taking away the safety net of the secular legal system underpinned as it is, by universal human rights values to which minority women have contributed through their struggles. In doing so, it accepts the view propounded by religionists that the principles of individual choice and autonomy are 'western' or 'alien' concepts and encourages the development of parallel legal systems. The incorporation of the MAT within the legal system directly contravenes the UK's obligations under the domestic and international human rights law, which is to protect women and children from acts of violence committed in public or private spaces. The duty to exercise due diligence, in order to prevent, investigate and punish acts of violence against women, including those carried out by non-state actors is a necessary function of a democratic state and the democratic principle. This duty is clearly being subverted as the above quote on how the MATs deals with domestic violence cases show. Instead of encouraging women to seek redress or accountability through the courts, the aim of the MAT is solely to resolve family matters informally, precisely in order to avoid the scrutiny of the state.

In response to criticisms about the formalisation of legally binding religious arbitration systems, supporters of the MAT argue that it is an important vehicle for the expression of Muslim female 'choice' and 'autonomy' and that regulation of the system is all that is required to address gender discrimination. ${ }^{20}$ This perspective, which at first glance appears seductive, fails to grasp two crucial problems. First, that the question of the exercise of choice and autonomy for most minority women cannot be divested from the social, political and economic power dynamics that exist within and without minority communities which usually protect vested patriarchal interests. Second, the need to save state resources is precisely why any attempts to regulate religious tribunals will ultimately fail, since the type of effective regulation required would defeat the object of the exercise, which is to save resources and time. Global research conducted by the International Council for Human Rights Policy in Geneva, suggests that mechanisms for regulation in any case are wholly absent, and that states that have established separate religious laws are very reluctant to intervene in their functioning to regulate or reform them. The inevitable consequence is that the laws of the minority will remain unreformed for decades (International Council on Human Rights Policy 2009).

\subsection{Contradictory developments in the law's response to women's human rights}

Notwithstanding the demand for greater 'religious literacy' within the English legal system, English judges from time to time have safeguarded the rights of minority women, despite accusations of 'Islamaphobia' or religious insensitivity. Although not a uniform occurrence, there have been some very welcome judgements in the courts. 
In a recent case involving childcare proceedings, Lord Justice Wall (2009) emphatically stated that religious law cannot be allowed to trump concerns about the physical safety of children. In this case, a Muslim father of children under 11 years of age, sought to challenge the placement of his children with a non-Muslim foster family in circumstances where the children had suffered horrific abuse. Dismissing evidence from a Muslim scholar who appears to have argued that placing the children with a non-Muslim family would exacerbate the physical risk to the children by making the matter more public, thereby increasing the shame and dishonour wrought on the family, the judge argued that the correct priority was the physical safety of the children.

The problem is that such insights about the arbitrary application of religious laws and their inherent bias in favour of patriarchal power do not appear to be creatively applied in other cases, nor do they influence social policy considerations or the wider political culture which is increasingly preoccupied with the desire not to cause religious offence. In other words, attempts to address the clash between key rights, for example the right to manifest religion and the right to gender equality in legal judgements, are often ignored in state social policy and practice towards minority communities.

The tendency to show deference to religious values is usefully illustrated in a rape case that came to SBS's attention in 2006..$^{21}$ The case concerned a traditional Muslim woman who was raped by her husband who was then prosecuted. However, at trial she claimed that her religious requirements meant that she could not take part in a public legal process involving men unrelated to her to whom she would have to answer questions of a sexual nature.

In response, the prosecution counsel requested the defendant to change to a female counsel, but that request was refused, presumably on the valid grounds that this interfered with the defendant's right to choose his own legal representation. The prosecution counsel then requested that the victim be allowed to give evidence via a videolink through a female interpreter so that she would not have to see or hear the defendant's barrister or indeed any other male within the court room.
To accommodate this request, the judge adjourned the hearings to obtain reports from a Muslim cleric in order to ascertain the position of Muslim women in public life. Following this report, on religious and cultural grounds, he permitted her to give her evidence and be crossexamined via videolink through a female interpreter.

It is easy to have a feminist kneejerk response to this case; to view the measures taken by the court as very necessary in a situation where there is a need to improve the notoriously low rates of prosecutions in rape cases. However, when examined more closely, the court's approach gives rise to some concern mainly because it came close to undermining the rules of evidence in order to allow for greater religious and cultural accommodation. The court's response was not about the valid need for witness protection or even about making the court process less intimidating for female rape victims, but about the need to 'respect' the religious identity of Muslim women as endorsed by the Muslim theological expert used by the court. In many other situations, the same religious framework used to determine state response to minority women can and will work against the interests of women precisely because it is not they but religious 'experts' who validate their responses. In a political climate where there is huge pressure on women to conform to standards laid down by fundamentalists and religionists, ${ }^{22}$ it is women who have the most to lose when the rule of law or important legal safeguards are undermined or when needs are determined upon the basis of religious identity. It therefore becomes all the more necessary to uphold the rule of law since women's freedom (from terror and torture within the context of the family) is as dependent on it as is the freedom of those who are targeted as so-called state 'terrorists'.

Far from empowering minority women, the court's approach is inhibitive because it inevitably draws on very narrow assumptions about religious identity. Yet, the approach taken by the court has been widely circulated by the police as a model on how to address religious and cultural issues within the criminal justice system. Ultimately, it is a disturbing case, since it is only a short step to accepting the view that Muslim and other ethnic minority women have no need to utilise the secular legal system, since they are 
governed by their own community or personal laws. Indeed, this is precisely what happened in Germany when a Moroccan Muslim woman was denied a divorce in the face of domestic violence by a judge who stated that as a Muslim woman, she was governed by the Koran and not the civil law of the land (Hari 2007). The decision was eventually overruled but the danger of adopting a culturally relativist approach is all too obvious.

\section{The role of religion in shaping public policy}

The speed with which the English legal system and indeed all public institutions are absorbing minority religious identity at the exclusion of all else, is alarming. One glaring example of this is the way in which the government has set up numerous advisory forums to discuss issues affecting minority communities but involving religious leaders or increasingly Muslim women as opposed to black and minority ethnic (BME) women only. For instance in 2002, the government set up the Muslim Women's Network UK (2006), which conducted a series of closed focus group discussions in 2006 to give voice to Muslim women's needs.

The report launched soon after by the Muslim Women's Network UK $^{23}$ identified many issues such as gender-based violence, immigration difficulties, community pressures, racism and the lack of political representation - most of which are not specific to Muslim women only. But by attributing such experiences to Muslim women, the state wittingly or unwittingly homogenises Muslim religious identity and isolates the experiences of Muslim women from those of other South Asian women with whom they share specific family values and norms, due to their common social, cultural and political histories of origin in the Indian sub-continent. For example issues of 'honour' and 'shame', which are central organising features of all South Asian families and beyond critical in controlling female sexuality, are increasingly being attributed to Muslim women only.

The strategy of isolating Muslim women's needs and presenting them as somehow 'different' from those of other South Asian women in particular is deliberate and divisive. It plays into the fundamentalist segregationist agenda and denies the overwhelming success of secular Asian women's projects organising against genderbased violence and discrimination across ethnicities, cultures and religion. The approach strongly undermines the solidarity that has been forged by minority women and encourages groups to compete for resources and separate provision based solely around religious identity.

Collaborations between state institutions and faith groups on issues that were once the terrain of black and minority feminists are now evident up and down the country. In July 2005, the Greater London Domestic Violence Project, for instance, organised a round table discussion on domestic violence with faith leaders from London's main religions, many of whom belonged to minority religions. But no secular feminist groups that had worked on domestic violence within minority communities were invited to be part of the same discussion. The effect of this is two-fold: first, it empowers community leaders to take responsibility for issues such as domestic violence without having to account to women in their communities; since they are encouraged to relate only with the state through engagement in inter-faith partnerships. Second, the absence of feminists and progressive groups from such discussions serves to de-legitimise feminist and secular approaches to social issues within minority communities.

This event led to the publication of a report entitled 'Praying for Peace'. While it does contain feminist analysis of domestic violence, it also encourages partnerships between faith leaders and the 'domestic violence sector' (white but not black and minority secular feminists) in addressing issues of domestic violence. Unsurprisingly, the entire debate on violence against women is circumscribed within a religious framework which by its very nature compromises progressive human rights language and principles. For example, the report utilises religious notions of 'karma' and 'sin', which clearly act as substitutes for the feminist notions of human rights, choice and autonomy. Perhaps the most significant aspect of the report is the emergence of a contract between state and religious leaders to tackle issues such as domestic violence, forced marriage and other forms of abuse within minority communities. But the trade-off is not about protecting minority women, but about the maintenance of public order in return for communal (family) autonomy. By appearing to take responsibility for issues like domestic violence or forced marriage in minority 
communities, religious leaders can expect increased state support and resources, which ultimately give them greater control over women (Greater London Authority 2006).

The reality of women's lives does not support the view that most minority women choose identity according to their faiths alone. In a study carried $^{24}$ out by SBS on the impact of the cohesion and faith-based agenda on women, the majority of women of various ages and religious backgrounds who were interviewed, expressed very strong negative sentiments of mistrust and alienation from religious-based leaderships within religious institutions. Of the 21 women interviewed, all except one professed to some form of religious belief and some held very strong personal religious convictions. But all of the respondents viewed religion as a matter of personal choice or belief, rather than the basis of a social identity. They did not express any sense of belonging to a faith-based community. In fact, their reality showed that they adopted fluid identities which often straddled different traditions and cultures, for example:

Tomorrow I go to celebrate Valentine's Day. Islam says we shouldn't dance. I used to get awards for dancing. I love celebrating Valentine's Day. I will wear red clothes and red lipstick and get a red rose ... I wear lots of makeup and perfume. I also love celebrating Christmas and Easter. These are small pieces of happiness.

The vast majority of the women interviewed were adamant that they did not want religious authority to arbitrate on family matters. Reasons for this included memories of religious divisions in their countries of origin (the pain of partition of the Indian sub-continent was still raw for some); fear of breaches of confidentiality; fear of sexual exploitation ${ }^{25}$ and abuse of religious power; vulnerability to coercion and social compulsion to stay in the family; fear of not being listened to and fear of corruption, factionalism and struggles for power within religious institutions. In other words, they did not see religious institutions as simply religious institutions but as political entities involved in struggles for power and control over resources and people, especially women.

\section{Conclusion}

We have found that, despite challenges and protests from secular feminists, and subject to a few exceptions which serve only to prove the rule, there is no political will within or without the state to confront the problem of the erosion of the secular fabric of public culture in the UK. Liberals and anti-racists alike have uncritically embraced the view that the adoption of a political religious identity is inevitable and necessary in the struggle against imperialism and racism as signified by the 'war on terror'. While many have been critical of the state's cohesion agenda and the backlash against multiculturalism, few (if any) publicly acknowledge the close link between the promotion of the 'cohesion' agenda and the 'faith-based' approach to the management of race relations. Yet it is precisely this linkage which corrals minorities into specific reactionary religious identities and reinforces the tendency to value religious and cultural orthodoxy and conservatism, often imposed by powerful, illiberal and even fundamentalist religious forces within minority communities.

It is black and minority women who lose out in the ensuing silence, since their bodies are being used by the state to wage its 'war on terror' and by fundamentalists and religionists to safeguard the socioreligious identity of their communities. The reality of women's lives show that the struggle for secularism is the struggle for equality and human rights. The two struggles are now so inextricably linked that it is impossible to wage one without simultaneously waging the other. This is the true significance of SBS's successful challenge to Ealing Council: it highlighted the urgent need to develop a politics of solidarity within and between communities which recognises that what is at stake is no less than the fight for secular, progressive, feminist and anti-racist values - a fight which is embodied in our name. 


\section{Notes}

* This article is an abridged, revised version of a longer paper written for 'Women Living Under Muslim Law'.

1 I distinguish religious fundamentalism (the political use of religion) from religious observance, by following the definition developed by Women Against Fundamentalism: 'Religious fundamentalism refers to the rise of any modern religious political movements that exercise selectivity in the interpretation of its religious texts. Two features that are common to all fundamentalist religious movements stand out: first, they claim their version of religion to be the only true one and feel threatened by pluralist systems of thought; and second, they use political means by which to impose their version of the truth on all members of their religion. Fundamentalism is a term that can apply to all religions but at the heart of all fundamentalist movements is support for the patriarchal family as a central agent of control. And women are viewed as embodying the morals and traditional values of the family and whole community. These movements demand absolute conformity to religious laws as interpreted by male religious leaders and deny the countless religious interpretations, traditions and practices that have evolved within a religion' (Sahgal and Davies 1992).

2 See Gita Sahgal (Sahgal and Davies 1992).

3 For a history and account of the work of Southall Black Sisters, see Southall Black Sisters (1990) and Gupta (2003).

$4 \mathrm{R}$ (on the application of Kaur and Shah $v$ London Borough of Ealing. [2008] EWHC 2062 (Admin).

5 The accepted definition of 'community cohesion' agreed by the Improvement and Development Agency (IDeA), the LGA (Local Government Association) and the Home Office was first published in the LGA's Guidance on Community Cohesion (2002).

6 See Ealing's Shared Future: Integration and Community Cohesion Strategy 2007-2011. The following objectives dominate Ealing's cohesion strategy, although they are by no means exhaustive: work with faith-based groups; publish a faith directory; hold interfaith conferences and improve inter-faith working; deliver Ealing Muslim Community engagement project by working with Muslim children and young people on issues, problems and social tensions affecting Muslims and how to engage Muslim communities to engage in the formation of public policy; deliver a faith volunteering project for schools, hospitals and the police targeting Muslim volunteers; provide conflict mentoring training for young Muslim children and people; hold a conference that will emphasise a scholarly interpretation of Islam that supports integration and citizenship; launch a Muslim network; build the capacity of third sector organisations that will explore the values of Islam; develop questionnaires to gather the views of Muslims.

7 See The Islamic Right-Key Tendencies (Awaaz 2006), which traces the roots of the Muslim Council of Britain to the long-standing Islamic Right political party - the Jamaati-I-islami (JI) from the Indian sub-continent, www.awaazsaw.org/awaaz_pia4.pdf. Awaaz is a UK-based secular network of organisations and individuals set up to monitor religious hatred in South Asia and the UK. Awaaz has also researched the links between so-called 'moderate' Hindu organisations, such as the Hindu Forum of Britain and the Hindu Council UK and Hindu Right organisations in India responsible for fomenting hatred and violence against Muslims. It also notes that in April 2006, Ramesh Kallidai, the General Secretary of the Hindu Forum was appointed commissioner by the Commission on Integration and Cohesion. Awaaz has exposed him as a sympathiser if not promoter of Hindu fascism. In April 2006 for instance, he attended a meeting of the Hindu Swayamsevak Sangh (HSS), a British branch of the RSS - a fascist organisation in India that promotes Hindu supremacist ideology - where he paid homage to a previous leader of the RSS who extolled the virtues of Nazi Germany. The RSS has been widely blamed for large scale anti-minority violence in India and one of its former members was responsible for the murder of Mahatma Gandhi.

8 The term 'moderates' is peculiar to discussions following the 9/11 bombings in New York and is often used by the US and European states to distinguish between 'extreme' and so-called 'moderate' Muslims. Those Muslims who claim to advocate moderation in respect of religious or political beliefs and to uphold the rule of law (usually with reference to public order) are deemed to 
be 'Moderates'. It is however, a contested term which is firmly located within the politics of the 'war on terror'.

9 For example, in 2007, in the UK, the Roman Catholic Ghurch threatened to close all its adoption and fostering agencies because of new equality legislation, which made it unlawful for agencies to discriminate against gay couples wanting to adopt or foster children. The Ghurch was seeking an exemption from the equality legislation pertaining to sexual orientation. We fear that religious institutions in all religions will seek to legitimise sexual or gender discrimination by claiming religious privilege and by doing so, exclude from their services those who do not share their religious values.

10 By this, I mean forms of protest that seek to use fear and intimidation to impose a particular interpretation of religion on the population.

11 Over the years, there have been a number of protests within minority populations that reflect growing intolerance of dissent from within. The Muslim fundamentalist protests against Rushdie in 1989, is only one of a growing number of protests. In 2006, Hindu fundamentalists attempted to use the language of human rights to stop an exhibition of paintings in London by the renowned Indian painter M.F. Hussain. They argued that the naked depiction of female deities offended 'Hindu' religious sensibilities - although their claim to represent all Hindus was never challenged by the organisers of the exhibition. Of course, dissent is not confined to minorities - in December 2004, Christian fundamentalists, led by the organisation Christian Voice, demonstrated outside the offices of the BBC against the broadcast of Jerry Springer, the Opera, on the grounds that it was blasphemous.

12 In this context, the term 'orthodox' refers to adherence to conventional or traditional religious doctrine, whereas 'fundamentalism' refers to modern political movements that use modern means of communication to impose a strict and selective interpretation of a religious text on the basis that it is the only 'true' interpretation.

13 See Saghal and Davies (1992).

14 See for example, 'Civil and Religious Law in England: A Religious Perspective', a lecture delivered by the Archbishop of Canterbury at the Royal Courts of Justice on 7 February 2008.
15 See Abul Taher 'Revealed: UK's first official Sharia courts', Times Online, September 2008. See also Muslim Arbitration Tribunal, at www.matribunal.com

16 The Muslim Arbitration Tribunal announces itself on its website in the following way: 'The Muslim Arbitration Tribunal (MAT) was established in 2007 to provide a viable alternative for the Muslim community seeking to resolve disputes in accordance with Islamic Sacred Law and without having to resort to costly and time consuming litigation'. See Muslim Arbitration Tribunal, at www.matribunal.com

17 Women Against Fundamentalism was formed in 1989 to challenge the rise of fundamentalism in all religions. Its members include women from a wide range of backgrounds and from across the world. See www.womenagainstfundamentalism.org.uk

18 See, for example Hirani v Hirani [1983] 4 F.L.R. 232. P v R [2003] 1 F.L.R. 661 and Re M Minors (repatriated orphans) [2003] EWHC 852. In these cases, the English courts have for example recognised forced or imposed marriages in circumstances of duress and/or where undue pressure has been applied but not those where a petitioner has simply consented to a marriage out of a sense of 'duty'.

19 For more information, see www.matribunal.com

20 This is a common argument made by some Muslim scholars, including feminist scholars in the UK (Malik 2008). While appearing to provide ways of negotiating competing interests in equality and human rights in the British context, the paper is devoid of any sociopolitical analysis that gives rise to demands for separate religious arbitration systems and fails to refer to the contestations that are taking place between feminists and fundamentalists in the legal arena. For example, in her analysis of the Shabina Begum $v$ Denbigh High School case, there is a complete absence of any examination of the social and political pressure exerted by Shabina's brother and a Muslim fundamentalist group that advocated on her behalf and there is also no consideration given to the impact of growing fundamentalist demands for recognition of religious dress codes on other Muslim girls in the school who feared that they too would be pressurised into wearing the jilbab. Her paper also quotes with approval, the attempts by Marion Boyd, the former 
Attorney General of Ontario, Canada, to legitimise and regulate Muslim arbitration systems within Ontario's civil legal system. However, it fails to mention that this development was contested by Canadian Muslim women, who in coalition with other women, eventually won a vital victory against the attempts to severely limit women's universal access to equality and human rights. See, for example Canadian Council of Muslim Women (2007).

21 The details of this case were circulated to the SBS among other organisations, on 20 October 2006 by fax, by a police Inspector from the Specialist Crime Directorate of the Metropolitan Police Force.

22 The term refers to those who strictly adhere to religious tenets and values only.

23 The Muslim Women's Network UK is an independent network of Muslim women who seek to provide a 'channel' between Muslim

\section{References}

Awaaz (2006) The Islamic Right - Key Tendencies, www.awaazsaw.org/awaaz_pia4.pdf

Bennoune, K. (2007) 'Secularism and Human Rights: A Contextual Analysis of Headscarves, Religious Expression, and Women's Equality under International Law', Columbia Journal of Transnational Law

Canadian Council of Muslim Women (2007) Canadian Muslim Women at the Crossroads: From Integration to Segregation?, Gananoque, ON: CGMW

Commission on Integration and Cohesion (2007) Our Shared Future, Wetherby: Communities and Local Government Publications, www.integrationandcohesion.org.uk/ Our_final_report.aspx

Department for Communities and Local Government (2008) Guidance for Funders, London

Ealing Council (2008) Preventing Violent Extremism; 2008-09 Programme, Ealing: Ealing Council

Ealing Council (2007) Ealing's Shared Future: Integration and Community Cohesion Strategy 2007-2011, Ealing: Ealing Council

Greater London Authority (2006) 'Praying for Peace': Domestic Violence and Faith Communities Round-table Report, London: GLA women and the British State to ensure that they have equality of opportunity and an effective voice. See www.mwnuk.co.uk/content.php?id=84

24 Following SBS's victory in challenging Ealing Council under the Equality legislation, a pilot study was carried out by SBS with funding from Oxfam UK. The goal of the study was to assess the impact and process of the cohesion agenda and to bring the severely marginalised voices of women from ethnic minority groups within the UK into the debate on community cohesion. A report on the findings will be published by SBS in winter 2010 .

25 In the study, a significant number of women recounted cases where religious authorities had abused their positions of power. A particularly common fear that emerged was the fear of being sexually abused by figures of religious authority.

Gupta, R. (ed.) (2003) From Homebreakers to Jailbreakers, London: Zed Books

Hari, J. (2007) 'How Multiculturalism is Betraying Women', The Independent, 23 October

International Council on Human Rights Policy (2009) When Legal Worlds Overlap. Human Rights, State and Non-State Law, Versoix: ICHRP

Local Government Association (2002) Guidance on Community Cohesion, London: LGA

Malik, M. (2008) From Conflict to Cohesion: Competing Interests in Equality Law and Policy, paper for the Equality and Diversity Forum, London: EDF

Muslim Women's Network UK (2006) She Who Disputes; Muslim Women Shape the Debate, London: Women's National Commission Sahgal, G. and Yuval Davies, N. (eds) (1992) Refusing Holy Orders: Women and Fundamentalism in Britain, London: Virago

Southall Black Sisters (1990) Against the Grain, Southall, Middlesex: Southall Black Sisters

Taher, A. (2008) Revealed: UK's First Official Sharia Courts, www.timesonline.co.uk

Wall, Lord Justice (2009) “"Honour” Crimes Have No Place in English Law', The Guardian, 17 March 